\title{
Functional Problems of a Teachers College Library
}

\section{Mr. Burke is librarian, George Peabody College for Teachers.}

$\mathrm{T}_{\mathrm{t}}$

HE latest Education Directory reveals that 717 institutions of higher learning in the United States have for one of their definite purposes the preparation of teachers. $^{1}$ In view of the dearth of teachers in these postwar years, the importance and significance of these colleges and their contributions to education cannot be ignored. Their influence extends far beyond the 170,205 students reported enroled in teacher-training colleges in $1948 .^{2}$ Superficially, it might seem that such a heavy enrolment would indicate that there is an adequate supply of teachers. This conclusion, however, is not warranted, for the teacher lag continues. The National Education Association reported at the conclusion of 1949 that there was a need for 140,402 teachers. $^{3}$ In October of 1950 , concerning itself only with the needs for elementary schools, the N.E.A. reported a shortage of 75,000 teachers. The supply, on the other hand, was estimated at 25,000 or a deficiency of some 50,000 in the first eight grades of school. ${ }^{4}$

While this deficiency in the numbers of trained teachers may account in part for the heavy enrolments in teachers colleges, certain agencies within the colleges themselves are being called upon to perform

1 U. S. Office of Education. Education Directory, Higher Educrtion, 1949-50. Part 3. Washington, U. S. Government Printing Office, 1950, p. Io.

${ }^{2}$ World Almanac, I050. p.572.

3 N.E.A. Research Bulletin, $27: 138$, December 1949

NEA News, 4:2, Oct. 6, I950.
I herculean tasks as they serve a student population that is greater in numbers and demands than ever before. One of these is the library. The purpose of this article is to consider how the library of the teachers college has fared in its functional aspects as enrolments have mounted.

First, let us agree on what is meant by "function." Good defines "functional" as pertaining to operation or action, but not to structure or substance. ${ }^{5}$ However, if one is to realize any aim or objective he must first understand that objective completely and believe in it just as completely. This is the premise on which library science and service are built. Next he must have the necessary equipment to carry out such objectives. The functioning of a library is so completely dependent upon funds to maintain and promote the program and upon personnel to administer the library that we can hardly look at one without considering the other.

\section{Library Expenditures}

One of the first aspects, then, to be considered in the total picture is that of funds. There is evidence that inadequate budgets constitute a major problem. In an appraisal of teachers college libraries in one state, this conclusion is drawn: "Until administrators of the colleges, members of the state legislature and the citizens of Minnesota are aware of the importance of funds for these colleges and their librariec,

5 Good, Carter V. Dictionary of Education. New York, McGraw-Hill, r945, p.r8o. 
great expansion of service cannot take place." 6

It might be well to examine some figures comparing library expenditures of teachers colleges with total college expenditures of the same institutions. (Table I)

Table I7

Total Library Expenditures Compared with Total College Expenditures

\begin{tabular}{|c|c|c|c|c|}
\hline \multirow{2}{*}{$\begin{array}{l}\text { Year } \\
193^{8}\end{array}$} & \multicolumn{2}{|c|}{$\begin{array}{c}\text { Library } \\
\text { Expenditures }\end{array}$} & \multicolumn{2}{|c|}{$\begin{array}{c}\text { College } \\
\text { Expenditures }\end{array}$} \\
\hline & $\begin{array}{l}\text { High } \\
\text { Median } \\
\text { Low }\end{array}$ & $\begin{array}{r}\$ 43,389 \\
10,045 \\
3,402\end{array}$ & $\begin{array}{l}\text { High } \\
\text { Median } \\
\text { Low }\end{array}$ & $\begin{array}{r}\$ 571,230 \\
233,211 \\
63,360\end{array}$ \\
\hline 1940 & $\begin{array}{l}\text { High } \\
\text { Median } \\
\text { Low }\end{array}$ & $\begin{array}{r}\$ 59,482 \\
10,926 \\
3,505\end{array}$ & $\begin{array}{l}\text { High } \\
\text { Median } \\
\text { Low }\end{array}$ & $\begin{array}{r}\$ 626,416 \\
197,923 \\
62,476\end{array}$ \\
\hline 1942 & $\begin{array}{l}\text { High } \\
\text { Median } \\
\text { Low }\end{array}$ & $\begin{array}{r}\$ 59,050 \\
11,261 \\
4,307\end{array}$ & $\begin{array}{l}\text { High } \\
\text { Median } \\
\text { Low }\end{array}$ & $\begin{array}{r}\$ 587, \infty 00 \\
188,631 \\
78,380\end{array}$ \\
\hline 1946 & $\begin{array}{l}\text { High } \\
\text { Median } \\
\text { Low }\end{array}$ & $\begin{array}{r}\$ 76,5 \mathrm{I} 4 \\
\mathrm{I}_{4}, 844 \\
5,8 \mathrm{I} 9\end{array}$ & $\begin{array}{l}\text { High } \\
\text { Median } \\
\text { Low }\end{array}$ & $\begin{array}{r}1,096,375 \\
300,193 \\
90,799\end{array}$ \\
\hline I947 & $\begin{array}{l}\text { High } \\
\text { Median } \\
\text { Low }\end{array}$ & $\begin{array}{r}\$ 85,507 \\
13,069 \\
5,847\end{array}$ & $\begin{array}{l}\text { High } \\
\text { Median } \\
\text { Low }\end{array}$ & $\begin{array}{r}1,393,069 \\
343, \text { I I } 3 \\
\text { I I } 5,622\end{array}$ \\
\hline I949 & $\begin{array}{l}\text { High } \\
\text { Median } \\
\text { Low }\end{array}$ & $\begin{array}{r}5128,106 \\
21,981 \\
7,245\end{array}$ & $\begin{array}{l}\text { High } \\
\text { Median } \\
\text { Low }\end{array}$ & $\begin{array}{r}1,962,244 \\
625,000 \\
225,000\end{array}$ \\
\hline
\end{tabular}

These figures seem to indicate that the total library expenditures in 1949 were slightly less in proportion to total college expenditures as they were in 1938 .

\section{Book Collections in Teachers Colleges Libraries}

The use of a college and university library, as well as the usefulness of that library to the educational institution it serves, might be evaluated on the nature

6 Larson, Beulah M., "Appraisal of Teachers College Libraries." Minnesota Libraries, I $5: 305$, June 1948.

7 "Teachers College and Normal School Library General and Salary Schedule." A.L.A. Bulletin, 33:199, February 1939; 34:133-35, February 1940; 35:113-16, February 1939; 34:133-35, February 1940; 35:113-I6,
February 1941; 36:129-31, February 1942. College

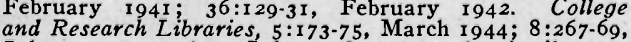
and Research Libraries, $5:$ I 73-75, March I $944 ; 8: 267-69$,
July I $947 ; 9: 246-50$, July 1948; I I : I 5 I-63, April I950. and size of its book collection. The type of material in a teachers college library should necessarily be of a nature which not only attempts to help the college attain its broad objectives of education, but should also contain professional works allied to its curricular program. How can such a collection be evaluated? Needless to say such an attempt or study would be beyond the range of this paper.

Much the same would be true of the size of the collection. Here it is possible to mention only some statistics concerning the size of such libraries and expenditures per student. The four largest teachers college libraries are located at Teachers College, Columbia (250,000 volumes); George Peabody College (I 85,00o volumes); Indiana State Teachers College ( 1 53,000 volumes); and Iowa State Teachers College ( 140,000 volumes).$^{8}$ A survey in 1933-34 covering 39 teachers colleges showed an average of 39.5 volumes for each student in attendance and an expenditure of $\$ 12.96$ per student for library purposes. The average number of books per library was $24,000 .^{9}$

Book stocks in teachers colleges naturally have continued to rise. A study of the rate of rise alone would be pertinent to this study. Any attempt to establish a ratio between total library expenditures and acquisitions, however, would involve many factors outside the scope of this article in order to be meaningful. Numerical increase alone would not be a true indication of the amount of the library's budget expended for book purchase for two reasons: first, the steady increase in the cost of books in the past few years; and second, the increasing amounts spent by libraries for nonbook materials.

8 "Libraries in Teachers Colleges." Encyclopedia Americana, I 7:3572, 1949 . ${ }^{9}$ Gourley, J. E., and Mohrhardt, F. E., "Teachers College Libraries."' Wilson Library Bulletin, 14:662-63, May 1940. 


\section{Salary Levels Have Risen}

The importance of having capable and efficient personnel (and holding such persons) is of paramount concern in any library as well as in those of teachers colleges. Generally speaking, the charcteristics of today's librarians include a thorough background in the knowledge and experience of the profession, intelligence and scholastic success. Intelligence means mental ability and to a certain extent the ability to acquire knowledge quickly and efficiently. Scholastic success indicates accomplishment in a given course of study and the satisfactory completion of an educational program. Other characteristics are interest in and enthusiasm for education, demonstrated ability to meet and deal effectively with others, conscientiousness and integrity.

Functionally, while the successful operation of a library from the standpoint of personnel is dependent upon many factors, at least two aspects may be considered here as affecting in some pertinent way the efficiency of a teachers college library. The first of these concerns the salary scale (an important aspect of morale) and the other, the adequacy of personnel to serve the students of teachers colleges. ${ }^{10}$

First of all, a study of salaries can be computed proportionately with total library and college expenditures. There are no outside factors involved in such a comparison; either salary increments have kept pace with expenditures or they have not. This article will indicate only that they have risen steadily from 1939 through I 949 ; no attempt will be made to establish proportions. Table II shows high, median and low salaries for professional librarians only.

10 Burke, John Emmett, "Factors Contributing to Faculty Morale in Teachers Colleges." The Teachers College Journal, 22:2, October I950.
Table II'11

Salary Range of Professional Librarians

\begin{tabular}{|c|c|c|c|c|}
\hline Year & \multicolumn{2}{|c|}{$\begin{array}{l}\text { Chief } \\
\text { Librarian }\end{array}$} & $\begin{array}{l}\text { Dept. } \\
\text { Heads }\end{array}$ & Assts. \\
\hline I $93^{8-39}$ & $\begin{array}{l}\text { High } \\
\text { Median } \\
\text { Low }\end{array}$ & $\begin{array}{r}\$ 3,750 \\
2,200 \\
1,850\end{array}$ & $\begin{array}{r}\$ 2,400 \\
1,925 \\
1,400\end{array}$ & $\begin{array}{r}\$ 2,200 \\
I, 800 \\
I, 400\end{array}$ \\
\hline I $939^{-40}$ & $\begin{array}{l}\text { High } \\
\text { Median } \\
\text { Low }\end{array}$ & $\begin{array}{r}\$ 4,000 \\
2,400 \\
1,850\end{array}$ & $\begin{array}{r}\$ 2,400 \\
1,900 \\
1,400\end{array}$ & $\begin{array}{r}\$ 2,000 \\
\text { I, } 800 \\
\text { I, } 100\end{array}$ \\
\hline I940-4I & $\begin{array}{l}\text { High } \\
\text { Median } \\
\text { Low }\end{array}$ & $\begin{array}{r}\$ 3,750 \\
2,408 \\
1,695\end{array}$ & $\begin{array}{r}\$ 2,800 \\
2,000 \\
1,400\end{array}$ & $\begin{array}{r}\$ 2,400 \\
1,740 \\
1,260\end{array}$ \\
\hline $194 I-42$ & $\begin{array}{l}\text { High } \\
\text { Median } \\
\text { Low }\end{array}$ & $\begin{array}{r}\$ 4,000 \\
2,500 \\
1,920\end{array}$ & $\begin{array}{r}\$ 2,800 \\
2,200 \\
1,500\end{array}$ & $\begin{array}{r}\$ 2,800 \\
1,805 \\
1,350\end{array}$ \\
\hline $1945-46$ & $\begin{array}{l}\text { High } \\
\text { Median } \\
\text { Low }\end{array}$ & $\begin{array}{r}\$ 3,984 \\
2,900 \\
2,750\end{array}$ & $\begin{array}{r}\$ 3,740 \\
2,681 \\
2,100\end{array}$ & $\begin{array}{r}\$ 3,685 \\
3,150 \\
2,000\end{array}$ \\
\hline $1946-47$ & $\begin{array}{l}\text { High } \\
\text { Median } \\
\text { Low }\end{array}$ & $\begin{array}{r}\$ 4,660 \\
2,985 \\
1,980\end{array}$ & $\begin{array}{r}\$ 3,240 \\
2,650 \\
1,800\end{array}$ & $\begin{array}{r}\$ 2,911 \\
2,220 \\
1,565\end{array}$ \\
\hline I $948-49$ & $\begin{array}{l}\text { High } \\
\text { Median } \\
\text { Low }\end{array}$ & $\begin{array}{r}\$ 5,912 \\
4,250 \\
2,400\end{array}$ & $\begin{array}{r}\$ 3,850 \\
3,150 \\
2,400\end{array}$ & $\begin{array}{r}\$ 4,289 \\
2,950 \\
2,026\end{array}$ \\
\hline
\end{tabular}

\section{Library Staff Increases Vary}

How have library staffs in teachers colleges fared with the increase in student enrolments? One method of answering that question is to establish relative figures of the numbers of librarians and teachers employed on the faculties of teachers colleges through a span of years. A comparison of the number of faculty members and the professional staffs of the libraries shows the unevenness with which teachers college libraries have kept pace with the colleges themselves. The high figure in Table III shows that the library staff has developed evenly with the teaching faculty; the proportion is approximately the same in 1947 as it was in 1938. The low figure

11 "Teachers College and Normal School Library General and Salary Schedule." A.L.A. Bulletin, 33:199, February 1939; 34:133-35, February 1940; 35:113-16, February 1939; 34:133-35, February 1940; 35:113-16, February I94I; 36:I 29-31, February I942, College and
Research Libraries, 5:173-75, March 1944; 8:267-69, Research Libraries, 5:I73-75, March I $944 ; 8: 267-69$,
July I $947 ; 9: 246-50$, July 1948; II:I51-64, April I950. 
for librarians, however, has not changed while the number of faculty members in that same group has almost doubled since 1938. Table III compares professional library staffs with the teaching faculties of teachers colleges.

\section{The Use of the Library}

Generally speaking, it is not possible to measure all the functional aspects of the library. The use of a teachers college library is so intangible as to be very much impossible to measure accurately. Much has been written about lack of good service, and some standards have been set up so that libraries can attempt to measure to some degree the relative possibilities they have for good work and a method of selfanalysis for improvement of service. No attempt is made here to gauge the effectiveness of a teachers college library by comparing its circulation with its enrolment. Such a procedure would be highly questionable.

Suffice it to say that the library is an educational institution. Education is an awakening and a growth. Who can measure the stimulating or awakening power of many aspects of library activity which can never be recorded? These things defy measurements.

\section{The Future of Teachers College Libraries}

Naturally in studying the functional problems of teachers colleges libraries, a glance to the future is in order. What may this type of library expect in the years to come? As the teachers college rises or ebbs in importance, so will its library. A brief analysis, then, of school population trends may be considered.

Estimated population statistics for students in the fourth year of high school
Table III'12

Librarians and Teachers in Teachers Colleges

\begin{tabular}{|c|c|c|c|}
\hline Year & \multicolumn{2}{|c|}{ Librarians } & Teachers \\
\hline $193^{8}$ & $\begin{array}{l}\text { High } \\
\text { Median } \\
\text { Low }\end{array}$ & $\begin{array}{l}8 \\
3 \\
I\end{array}$ & $\begin{array}{r}150 \\
54 \\
13\end{array}$ \\
\hline 1939 & $\begin{array}{l}\text { High } \\
\text { Median } \\
\text { Low }\end{array}$ & $\begin{array}{l}9 \\
2 \frac{1}{2} \\
I\end{array}$ & $\begin{array}{r}136 \\
55 \\
16\end{array}$ \\
\hline 1940 & $\begin{array}{l}\text { High } \\
\text { Median } \\
\text { Low }\end{array}$ & $\begin{array}{l}\text { I I } \\
2 \frac{1}{2} \\
\text { I }\end{array}$ & $\begin{array}{c}165 \\
52 \frac{1}{2} \\
14\end{array}$ \\
\hline 1942 & $\begin{array}{l}\text { High } \\
\text { Median } \\
\text { Low }\end{array}$ & $\begin{array}{r}12 \\
3 \\
1\end{array}$ & $\begin{array}{r}194 \\
51 \\
19\end{array}$ \\
\hline I 943 & $\begin{array}{l}\text { High } \\
\text { Median } \\
\text { Low }\end{array}$ & $\begin{array}{r}13 \\
3 \\
1\end{array}$ & $\begin{array}{l}175 \\
15 \frac{1}{4} \\
22\end{array}$ \\
\hline I 946 & $\begin{array}{l}\text { High } \\
\text { Median } \\
\text { Low }\end{array}$ & $\begin{array}{r}13 \\
2 \\
1\end{array}$ & $\begin{array}{r}245 \\
63 \\
19\end{array}$ \\
\hline I 947 & $\begin{array}{l}\text { High } \\
\text { Median } \\
\text { Low }\end{array}$ & $\begin{array}{l}\text { I } 4 \\
2 \frac{1}{2} \\
I\end{array}$ & $\begin{array}{r}250 \\
45 \\
11 \frac{1}{2}\end{array}$ \\
\hline 1949 & $\begin{array}{l}\text { High } \\
\text { Median } \\
\text { Low }\end{array}$ & $\begin{array}{r}15 \\
3 \\
1\end{array}$ & $\begin{array}{r}318 \\
45 \\
30\end{array}$ \\
\hline
\end{tabular}

show a marked increase. In I95I it is estimated that there will be $1,283,000$ students in the fourth year of high school and $\mathrm{I}, 72 \mathrm{I}, 000$ by $1960{ }^{13}$ If the proportion of students who went from high school into teachers colleges increased in ratio from I 890 to I947, logically it can be assumed that a similar ratio will continue through 1960. It is a safe prediction to forecast a steady rise in enrolments in teachers colleges through 1960 and a continuing increase in importance of teachers college libraries in helping the institutions training teachers attain their objectives.

${ }^{13}$ Ibid. S. Bureau of the Census, Current Population Re. ports. Series P-25, No. 18. Washington, U. S. Government Printing Office, Feb. 14, 1949. 